\title{
PENTINGNYA TEMPAT PENITIPAN ANAK UNTUK WANITA BEKERJA DI KALANGAN IBU DOSEN DAN KARYAWAN FAKULTAS ILMU KESEHATAN
}

\author{
Zakiyah Yasin 1), Dian Ika Puspitasari, S.Kep.Ns., M.Kep 2) \\ 1) Dosen Fakultas Ilmu Kesehatan, Universitas Wiraraja, \\ 2) Dosen Fakultas Ilmu Kesehatan, Universitas Wiraraja \\ E-mail : zakiyahfik@wiraraja.ac.id 1) \\ E-mail : dianika.uwr@gmail.com 2)
}

\begin{abstract}
ABSTRAK
Kegiatan penitipan anak memiliki peluang cukup baik di tengah-tengah dinamika kehidupan modern, khususnya di perkotaan. Dimana pekerjaan adalah rutinitas sehari-hari yang tidak bisa ditinggalkan. Telah menjadi budaya untuk menitipkan anak kepada pengasuh, baby sitter, atau pun pembantu rumah tangga di rumah.Cukup dilema bagi para orangtua jika mereka menitipkannya kepada seseorang yang tidak bisa mengasuh anak dengan baik sehingga berdampak pada perkembangan si buah hati.

Beberapa di perusahaan Bagi karyawati tak perlu khawatir, karena mereka menyediakan fasilitas penitipan anak (day care) saat pengasuh anak mudik dan karyawan harus bekerja.. "Tujuannya, secara khusus untuk membantu karyawan yang harus menjaga anak-anaknya tetapi tetap harus bekerja, karena asisten rumah tangga mereka sudah "mudik" Lebaran," ungkap Thomas Purnawan Suhardja, Group Head Culture Transformation Indosat Ooredoo dalam keterangan Fasilitas penitipan anak yang disediakan berbeda dengan penitipan lainnya dan tergolong unik serta menarik.
\end{abstract}

Kata kunci : TPA, Ibu pekerja

\section{Pendahuluan}

Tempat penitipan anak (TPA) menjadi pilihan kala kedua orang tua bekerja. Tentu pemilihan TPA dilakukan dengan pertimbangan matang karena akan berpengaruh pada perkembangan sang anak.

Dalam hubungan itu, Depsos (2002) menegaskan bahwa yang dimaksud Taman Penitipan Anak adalah lembaga pelayanan pengganti sementara yang mengambil tanggung jawab secara luas ketika orangtua bekerja, yang meliputi pelayanan sosialisasi anak, pengembangan perilaku anak, pendidikan anak, kesehatan anak, kegiatan bermain, kegiatan pengisian waktu luang dan pelayanan sosial kepada orangtua/keluarga seperti pelayanan konsultasi anak dan keluarga ketika anak membutuhkan pelayanan tambahan.

Pengalaman peserta didik di dalam keluarga dan di lembaga PAUD berpengaruh besar terhadap positif atau tidaknya peserta didik ketika belajar. Layanan TPA yang berkualitas memiliki prinsip yang khas, meliputi: Tempa, Asah, Asih, Asuh. (Direktorat Pembinaan PAUD. 2013)

Menitipkan anak di TPA menjadi pilihan orang tua kala mereka harus bekerja dan sulit menemukan pengasuh bagi si buah hati. Atau justru kurang percaya terhadap 
sosok seorang pengasuh yang membuat orang tua berpikir ulang untuk meninggalkan anak dengan si pengasuh. Hal ini menjadi realita umum yang ditemui di kota besar. Bahkan pemerintah pun tidak menutup mata karena Undang- Undang No 13 Tahun 2003 tentang Ketenagakerjaan menyebutkan, pekerja atau buruh perempuan yang anaknya masih menyusui, harus diberi kesempatan sepatutnya untuk menyusui anaknya, termasuk selama jam bekerja.

(https://pendidikankita17.wordpress.com/2017/ 10/06/makalah-wanita-karir/).

Pelaksanaan pembelajaran sebagaimana dilakukan melalui bermain secara interaktif, inspiratif, menyenangkan, kontekstual dan berpusat pada peserta didik untuk berpartisipasi aktif serta memberikan keleluasaan bagi prakarsa, kreativitas, dan kemandirian sesuai dengan bakat, minat, dan perkembangan fisik serta psikologis peserta didik

\section{Bidang-bidang}

pengembangan pembelajaran anak usia dini di TPA dibagi menjadi dua yaitu, bidang pengembangan pembiasaan dan bidang pengembangan kemampuan dasar. (Aqib, Zainal. 2009).

Fasilitas penitipan anak yang disediakan berbeda dengan penitipan lainnya dan tergolong unik serta menarik. Pasalnya, mereka bekerja sama dengan mitra day care profesional dan berpengalaman, yang memiliki resources, fasilitas, dan program aktivitas yang menarik dan menyenangkan bagi anak-anak, sehingga tidak sekedar tempat penitipan anak biasa

\section{Metode}

Terdapat beberapa permasalahan utama yang menjadi dasar pemikiran sehingga Program Pengabdian Kepada Masyarakat perlu direalisasikan untuk ibu Dosen dan Karyawan di lingkungan Fakultas Ilmu Kesehatan yang memiliki putra putri usia balita atau paud. Diantara permasalahan tersebuat antara lain:

1. Dilingkungan Fakultas Ilmu Kesehatan masih banyaknya ibu karyawan dan Dosen yang belum memiliki tempat penitipan anak (TPA) yang layak dan berkualitas.

2. Peran Tempat penitipan anak cukup besar dalam peningkatan kinerja ibu karyawan dan dosen sehingga tidak mengkhawatirkan kondisi anak.

3. Intensitas pertemuan dengan putra putri berkurang dikarenakan jam kerja kator yang padat, padahal usia balita masih membutuhkan perhatian orang tua khususya ibu.

Berdasarkan permasalahan yang dialami oleh ibu ibu karyawan dan dosen di lingkungan Fakultas ilmu Kesehatan, maka Tim PKM Prodi Keperawatan Fakultas Ilmu Kesehatan Universitas Wiraraja Sumenep, melaksanakan penerapan tentang Pentingnya Tempat Penitipan anak (TPA) di Lingkungan Fakultas Ilmu Kesehatan diharapkan para ibuibu yang bekerja sebagai karyawan maupun dosen yang memiliki anak usia Balita dapat melakukan menitipkan putra putrinya di TPA Fakultas Ilmu Kesehaan dapat bekerja dengan tenang dan nyaman tanpa mengkhawatirkan keadaaan putranya karena ibu tetap mengetahui pertumbuhan dan perkembangan anak, serta anak mendapatkan tempat penitipan anak yang layak sehat dan berkualitas.

\section{Hasil dan Pembahasan}

Hasil kegiatan pengabdian di Fakultas Ilmu Kesehatan diikuti oleh dosen dan karyawan beserta anak balitanya sebanyak 20 orang dimana berdasarkan kegiatan yang telah dilakukan dalam bentuk ceramah dan Penerapan kegiatan pengabdian terdapat beberapa hasil evaluasi kegiatan diantaranya 


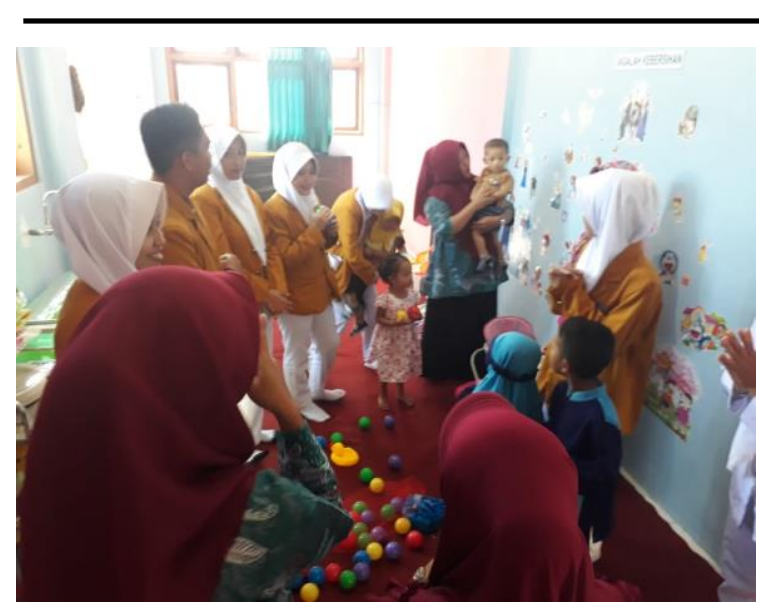

Gambar. 1 Kegiatan pengenalan di TPA

\section{A. Evaluasi Struktur}

1. Dekan Fakultas Ilmu Kesehatan beserta seluruh jajarannya dapat bekerja sama dengan baik dan kooperatif dibuktikan dengan dalam persiapan kegiatan dengan ikut serta menyiapkan atau membuat setting tempat Pengabdian.

2. Dekan Fakultas Ilmu Kesehatan beserta seluruh jajarannya tampak antusias menerima kunjungan dari tim PKM yaitu dosen Prodi S1 Keperawatan Universitas Wiraraja Sumenep.

B. Evaluasi Proses

1. Pelaksanaan penyuluhan dan penerapan kegiatan pengabdian terlihat aktif diikuti dosen dan karyawan yang mayoritas diikuti oleh dosen dan karyawan Fakultas Ilmu Kesehatan yang memiliki balita, dimana peserta terlihat aktif dalam berdiskusi serta mengikuti dan penerapan kegiatan pengabdian.

2. Peserta kegiatan dapat mengerti tentang Pentingnya Pemberian Imunisasi Dasar Lengkap Pada Anak Balita dibuktikan dengan para peserta dapat menjelaskan tentang Pentingnya

Pemberian

Imunisasi Dasar Lengkap Pada Anak Balita.

\section{Evaluasi Hasil}

Peserta kegiatan dapat mengerti dan memahami tentang Pentingnya Tempat Penitipan Anak Untuk Wanita Bekerja Di Kalangan Ibu Dosen Dan Karyawan Fakultas Ilmu Kesehatan

D. Keberlanjutan

Bagi Dosen Dan Karyawan Fakultas Ilmu Kesehatan perlu meningkatkan pengetahuan dan dapat memberikan informasi khusus tentang Pentingnya Tempat Penitipan Anak Untuk Wanita Bekerja, sehingga dapat memberikan manfaat kepada dosen dan karyawan di Universitas Wiraraja

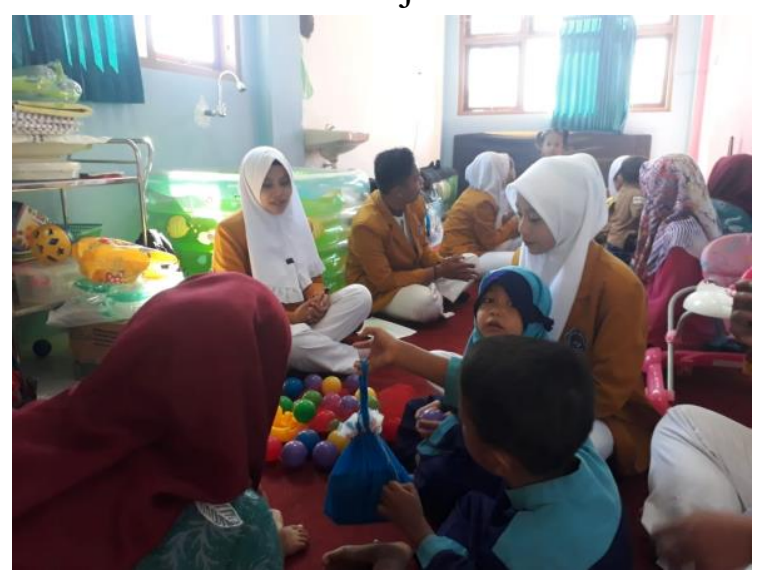

Gambar. 1 Kegiatan bermain bersama di TPA

$$
\text { Berdasarkan hasil kegiatan }
$$
penerapan tentang "Pentingnya Tempat Penitipan Anak Untuk Wanita Bekerja Di Kalangan Ibu Dosen Dan Karyawan Fakultas Ilmu Kesehatan” berdampak baik khusunya bagi Dosen Dan Karyawan yang memiliki bayi. Kegiatan pengabdian ini sebagaimana tertera di tabel berikut.

\begin{tabular}{|c|c|c|c|}
\hline No & Kegiatan Pengabdian & Respon Peserta & Waktu \\
\hline 1 & $\begin{array}{l}\text { Pendahuluan } \\
\text { * Memberi salam dan Berdoa } \\
\text { * Memberi pertanyaan apersepsi }\end{array}$ & $\begin{array}{l}\text { * Menjawab } \\
\text { salam }\end{array}$ & $10 \mathrm{mnt}$ \\
\hline
\end{tabular}




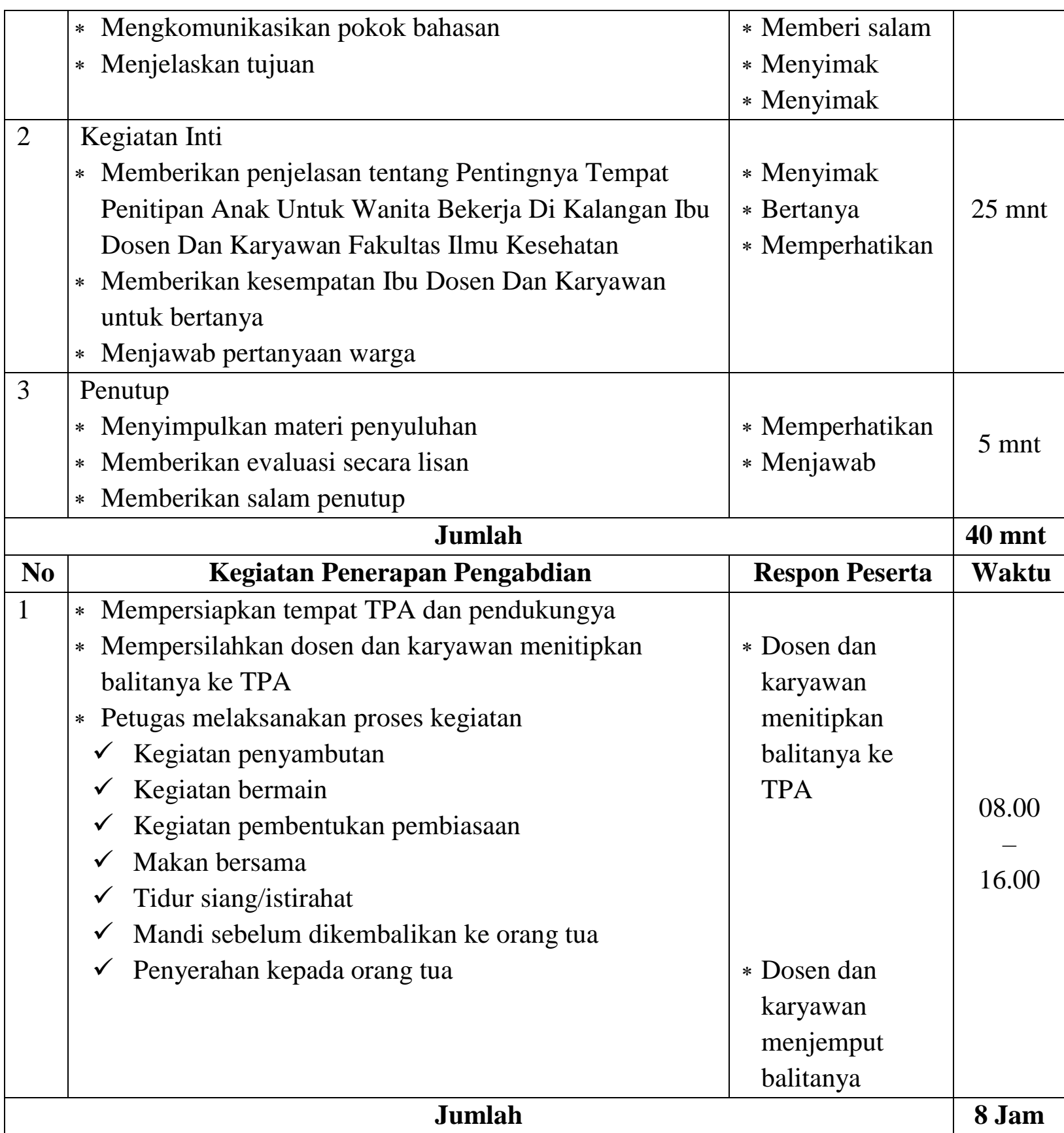

Tabel 1. Kegiatan selama PKM

\section{Simpulan}

Penyuluhan dan penerapan tentang Pentingnya Tempat Penitipan Anak Untuk Wanita Bekerja Di Kalangan Ibu Dosen Dan Karyawan Fakultas Ilmu Kesehatan berjalan dengan baik, sehingga berdasarkan hasil evaluasi, Dosen Dan Karyawan sangat antusias mengikuti penyuluhan dan penerapan tersebut dan sangat bermanfaat bagi Dosen Dan Karyawan khususnya Dosen Dan Karyawan yang yang memiliki balita.

Kegiatan Penyuluhan dan penerapan tersebut berdampak positif bagi Dosen Dan Karyawan di Lingkungan Fakultas Ilmu Kesehatan Universitas Wiraraja Sumenep, dengan harapan Tempat Penitipan Anak ini 
akan berjalan baik dan kontinu di masa yang akan datang.

\section{Ucapan Terimakasih}

Penyusunan PKM ini tidak lepas dari bantuan, dukungan serta bimbingan yang telah diberikan dari banyak pihak. Untuk itu perkenankanlah pelaksana mengucapkan banyak terima kasih dan penghargaan yang sebesar-besarnya terutama Dekan Fakultas Ilmu Kesehatan beserta jajarannya yang telah memberi waktu dan tempat untuk melaksanakan PKM ini.

\section{Daftar Pustaka}

Aqib, Zainal. (2009). Belajar dan Pembelajaran di Taman KanakKanak. Bandung :Yrama Widya

Direktorat Pembinaan PAUD. (2013). Petunjuk Teknis Penyelenggaraan Taman Penitipan Anak. Jakarta: Direktorat Jenderal Pendidikan Anak Usia Dini Nonformal Dan Informal

Depsos. 2002. Pedoman Penyelenggaraan Pelayanan Sosial Anak di Taman Penitipan Anak (TPA). Jakarta: Ditjen Bina Kesejahteraan Sosial Depsos RI.

Makalah Wanita Karir, Impian Seorang Santri. Diakses pada tanggal 15 Februari 2019 https://pendidikankita17.wordpress. com/2017/10/06/makalah-wanitakarir/ 